\title{
7. IN-SITU PORE-WATER SAMPLING AND DOWNHOLE TEMPERATURE MEASUREMENTS ${ }^{1}$
}

\author{
Shipboard Scientific Party ${ }^{2}$
}

\section{TEMPERATURE}

This chapter is a discussion of sediment temperature measurements for all Leg 117 sites. The "Explanatory Notes" chapter (this volume) includes a description of the water samplertemperature-pressure (WSTP) tool used during Leg 117. Temperature measurements were attempted at seven sites on Owen Ridge and the Oman margin. Temperatures were obtained at only five sites because of recorder malfunctions on five of the tool lowerings (see Table 1). The complete temperature records for each lowering are shown in Figures $1 \mathrm{~A}-1 \mathrm{~K}$.

All runs except 117-723C-6I-1 and 117-726A-4I-6 provide excellent undisturbed records of sediment temperature. During these two runs, temperatures started to drift upward after the water-sampling valve opened and pore fluid began to flow into the sampler filter element, which is $12-22 \mathrm{~cm}$ above the thermistor. The valve open time is indicated on all of the records by an arrow. The $200-250 \mathrm{~mL}$ of pore fluids filtered on the two runs depicted in Figures $1 \mathrm{~A}$ and $1 \mathrm{C}$ should not have significantly disturbed the sediment around the thermistor position in the tool. Indeed, no other temperature records show significant effects from fluid filtering except for a possible slight effect on run 117 . 727A-11I-1 (Fig. 1D).

Nevertheless, because of the apparent causal relationship between valve opening and temperature disturbance for runs 117 723C-6I-1 and 117-726A-4I-6, temperatures for these two runs were estimated from the record made prior to the valve opening. For the other runs listed in Table 1, temperatures were read from the end of the undisturbed (i.e., before the probe was pulled out of the mud) sediment record. Because the sediment temperature records are much longer than the 1-2-min time constant of the probe, no curve-fitting program was used to estimate equilibrium temperature.

We deployed the WSTP tool in the free-fall mode, which is possible during piston core/extended core barrel operations because the full diameter of the inner core barrel can extend through and beyond the drill bit. The temperature records displayed in Figure 1 show little, if any, disturbance caused by motion of the thermistor probe in the sediment; the one possible exception is run 1A-726A-4I-6 (Fig. 1C). These results contrast with the frequently disturbed records obtained in soft sediments when the sampler is latched into the drill string and the sampler probe is pushed into the sediment by the weight of the bottomhole assembly (Uyeda and Horai, 1982; Shipley and Shephard, 1982; Becker et al., 1983).

\section{Bottom Water Temperature}

The temperature probe was dropped into the sediment at high velocity and raised immediately to the ship after pullout. No mud-line temperatures were obtained. Thus, bottom water tem-

\footnotetext{
${ }^{1}$ Prell, W. L., Niitsuma, N., et al., 1989. Proc. ODP, Init. Repts., 117: College Station, TX (Ocean Drilling Program).

2 Shipboard Scientific Party is as given in the list of Participants preceding the contents.
}

peratures must be estimated from local or regional hydrographic data. At the shallowest Site 726, bottom water temperature was measured directly by an expendable-bathythermograph cast. For the other sites, some uncertainty resides in the assigned bottom water temperatures (Table 1). Based on the hydrographic section across the Arabian Sea at $15^{\circ} \mathrm{N}$ latitude (Sastry and D'Souza, 1971), all Oman margin sites are situated in the significant temperature gradient below the thermocline. Additional uncertainty is introduced by current- and upwelling-induced fluctuations of the isotherms as they intersect the continental slope off Oman. Additional hydrographic data may improve the estimates of bottom water temperature.

\section{Thermal Conductivity}

Thermal-conductivity values were measured over the same depth interval as the temperature measurements at Sites 727, 728 , and 731 ; in addition, thermal conductivity was measured at Site 720 on the Indus Fan where no temperature measurements were made. The Site 720 sediments are similar in composition to the deeper Owen Ridge sediments, so Site 720 thermalconductivity values might be useful in extrapolating the Site 731 thermal gradient to deeper parts of the sediment column. The thermal-conductivity measurements are presented and discussed in the "Physical Properties" sections of the respective site chapters in this volume. Only averaged values are presented here in Table 2. Thermal conductivity was not measured on cores from Sites 723 and 726 . Average thermal-conductivity values for these sites were estimated from the wet-bulk-density values for the respective sites and plots of wet-bulk density vs. thermal conductivity for the other Oman margin sites where thermal conductivity was measured (see "Physical Properties" sections, "Site 727" and "Site 728 " chapters). The upper sediments at all margin sites are similar in composition.

\section{Thermal Gradients and Heat Flow}

Figure 2 plots the combined temperature profiles for Leg 117 sites. The dashed line on the Hole $728 \mathrm{~B}$ profile is a straight-line extension of the gradient below $107 \mathrm{~m}$ below seafloor (mbsf). The lower thermal gradient at the top of Hole 728B and the higher thermal gradient in the 175-242 mbsf interval in Hole $731 \mathrm{~A}$ can be correlated with respective increased and decreased thermal-conductivity values in these depth intervals (see "Physical Properties" sections, "Site 728" and "Site 731" chapters), which counter the general trend of increasing thermal conductivity with increasing depth. The calculated heat flow for the $0-$ 50 mbsf and 107-233 mbsf depth intervals at Site 728 are similar (Table 2).

Table 2 lists the thermal gradients displayed in Figure 1, average thermal-conductivity values calculated from physical-property data, and the corresponding heat flow. Except for Site 726 (see the following discussion), the thermal gradient varies between 44 and $54 \mathrm{~K} / \mathrm{km}$ and the heat flow from 56 to $65 \mathrm{~mW} / \mathrm{m}^{2}$.

\section{Site 726}

Site 726 is on the edge of the Oman continental shelf about 5 $\mathrm{km}$ landward of the sharp shelf/slope break. The edge of the 


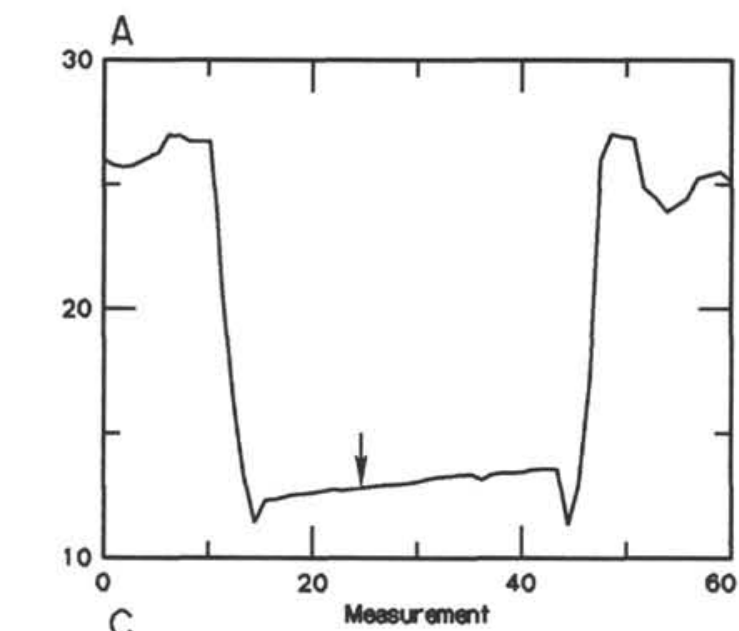

B

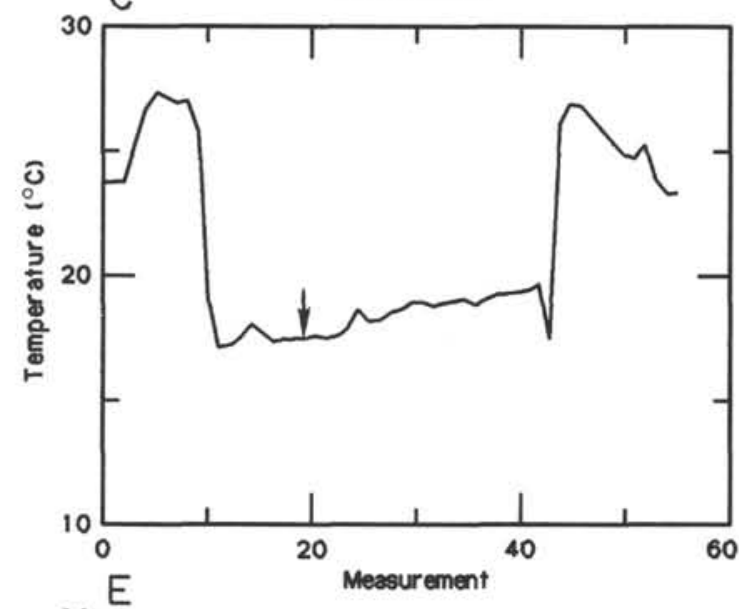

D
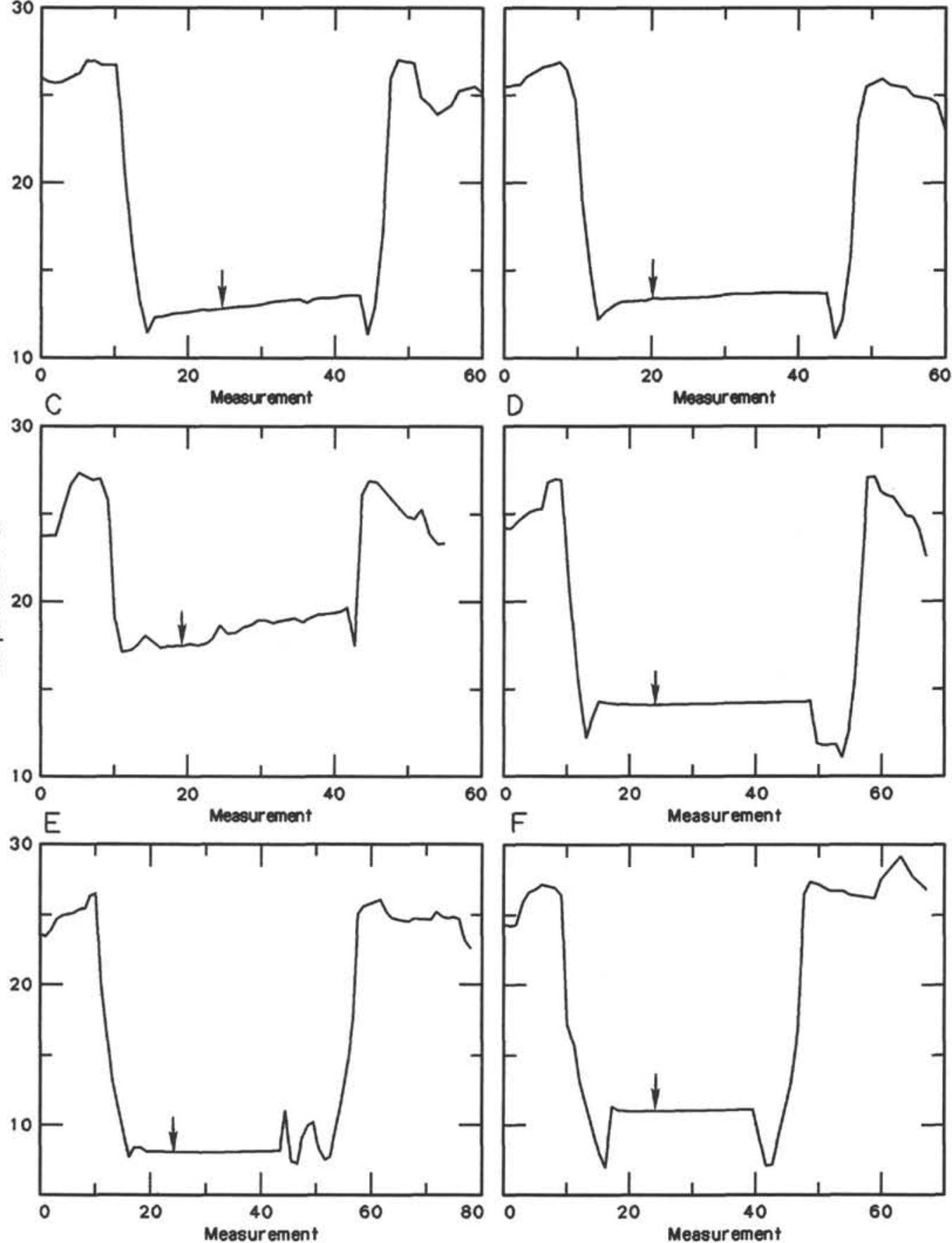

$\mathrm{F}$

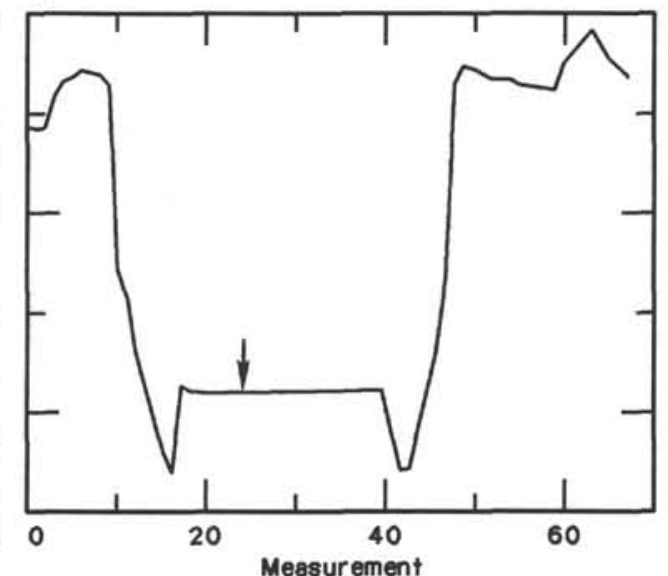

Figure 1. Downhole temperature records for WSTP tool runs. The arrows mark the time that the water sampler valve opened. A. Run 117-723C-6I-1, 49 mbsf. B. Run 117-723C-8I-1, 68.2 mbsf. C. Run 117-726A-4I-6, 36 mbsf. D. Run 117-727A-11I-1, 96.4 mbsf. E. Run 117-728B-7I-1, 49.5 mbsf. F. Run 117-728B-13I-1, 107 mbsf. G. Run 117-728B-18I-1, 155.4 mbsf. H. Run 117-728B-26I-1, 232.8 mbsf. I. Run 117-731A-7I-6, 66 mbsf. J. 117-731A-19I-1, 174.4 mbsf. K. 117-731A-26I-1, 242.3 mbsf.

shelf is underlain by block-faulted basement, thought to be an ophiolite complex (see "Background and Objectives" and "Summary and Conclusions" sections, "Site 726" chapter, this volume). The sediment section over basement is relatively thin, consisting of $131 \mathrm{~m}$ of hemipelagic sediments which is similar to other Oman margin sites that unconformably overlie porous shallow-water dolostones and limestones of Eocene age (see "Lithostratigraphy" section, "Site 726 " chapter).
The high thermal gradient at this site suggests the possibility of significant hydrothermal convection. The permeable, lithified carbonates below $131 \mathrm{mbsf}$ and the shallow basement high provide conditions conducive to fluid advection beneath the hemipelagic sediments. The single temperature measurement does not permit us to directly evaluate the possibility of vertical fluid flow through the thin hemipelagic cap. Fluids can be forced through sediments considerably thicker than those at Site $\mathbf{7 2 6}$ 


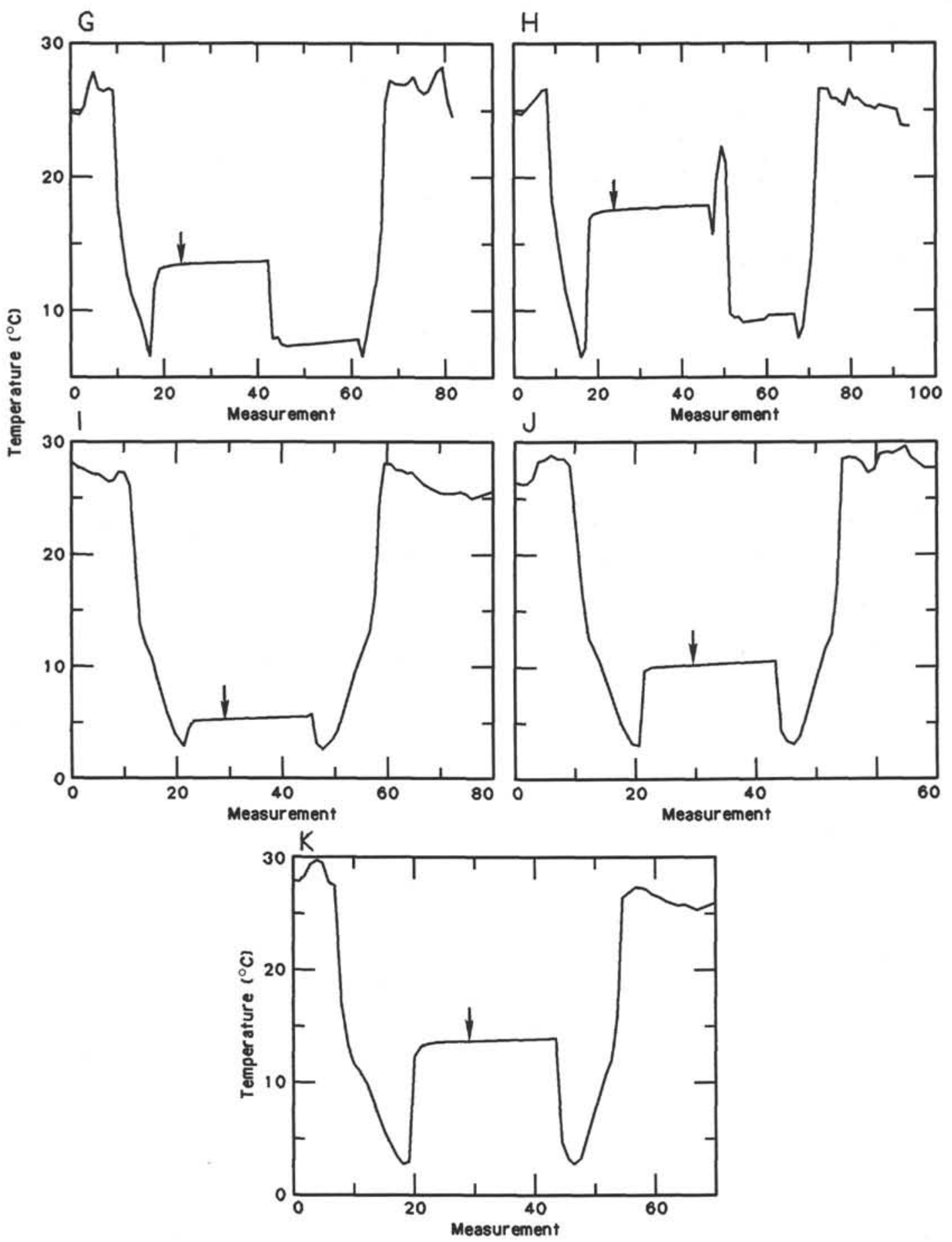

Figure 1 (continued).

when significant lateral hydraulic gradients exist at depth (Becker, Sakai, et al., 1988). However, the high thermal gradient to 36 mbsf could also reflect the upward movement of isotherms in response to upward fluid flow in the permeable rocks below the pelagic cap with little flow, if any, in the cap itself. Fluids could exit elsewhere, such as the block-faulted margin of the upper slope east of Site 726.

In contrast to other Oman margin sites, the pore-fluid chemistry at Site 726 also suggests the presence of a renewable pool of slightly hypersaline waters below the pelagic cap. These flu- ids are low in silica and only mildly affected by the diagenetic processes accompanying sulfate reduction (see "Inorganic Geochemistry" section, "Site 726 " chapter). These fluids diffuse (and advect?) into the pelagic cap, limiting the response of the pore fluids in the cap to the anoxic metabolic processes occurring there.

\section{REFERENCES}

Becker, K., Von Herzen, R. P., and Karato, S., 1983. Geothermal measurements from drilling of sediments near the Galapagos Spreading 
Center, $86^{\circ} \mathrm{W}$, Deep Sea Drilling Project Leg 70. In Honnorez, J., Von Herzen, R. P., et al., Init. Repts. DSDP, 70: Washington (U.S. Govt. Printing Office), 445-458.

Becker, K., Sakai, H., et al., 1988. Proc. ODP, Init. Repts., 111: College Station, TX (Ocean Drilling Program).

Sastry, J. S., and D'Souza, R. S., 1971. Oceanography of the Arabian Sea during southwest monsoon season, Part I: thermal structure. Indian J. Meteorol. Geophys., 21:367-382.

Table 1. Leg 117 downhole temperature measurements.

\begin{tabular}{|c|c|c|c|c|c|}
\hline Hole & $\begin{array}{l}\text { WSTP }^{\mathrm{a}} \\
\text { run }\end{array}$ & $\begin{array}{c}\text { Water } \\
\text { depth } \\
(\mathrm{m})\end{array}$ & $\begin{array}{c}\text { Sub- } \\
\text { bottom } \\
\text { depth } \\
\text { (mbsf) }\end{array}$ & $\begin{array}{c}\text { Temperature } \\
\left({ }^{\circ} \mathrm{C}\right)\end{array}$ & Source ${ }^{c}$ \\
\hline \multirow[t]{3}{*}{$721 \mathrm{C}$} & BW & 1945 & 0 & - & - \\
\hline & $12 \mathrm{I}-1$ & 1945 & 100.5 & NR & - \\
\hline & $16 \mathrm{I}-1$ & 1945 & 139.0 & NR & - \\
\hline \multirow{2}{*}{$722 \mathrm{~A}$} & BW & 2028 & 0 & - & - \\
\hline & $30 \mathrm{I}-1$ & 2028 & 281.0 & NR & - \\
\hline \multirow[t]{4}{*}{$723 C$} & BW & 808 & 0 & (10.3) & HYDRO \\
\hline & $6 \mathrm{I}-1$ & 808 & 49.0 & $*(12.83)$ & T-PROBE \\
\hline & $8 \mathrm{I}-1$ & 808 & 68.2 & 13.73 & T-PROBE \\
\hline & $91-1$ & 808 & 77.8 & NR & - \\
\hline \multirow[t]{2}{*}{$726 \mathrm{~A}$} & BW & 331 & 0 & 14.00 & XBT \\
\hline & $4 \mathrm{I}-6$ & 331 & 36.0 & $"(17.6)$ & T-PROBE \\
\hline \multirow[t]{3}{*}{$727 \mathrm{~A}$} & BW & 915 & 0 & $(10.0)$ & HYDRO \\
\hline & $4 I-6$ & 915 & 35.0 & NR & - \\
\hline & $111-1$ & 915 & 96.4 & 14.29 & T-PROBE \\
\hline \multirow[t]{5}{*}{$728 \mathrm{~B}$} & BW & 1428 & 0 & $(6.0)$ & HYDRO \\
\hline & $7 I-1$ & 1428 & 49.5 & 8.19 & T-PROBE \\
\hline & $13 I-1$ & 1428 & 107.0 & 11.13 & T-PROBE \\
\hline & $18 \mathrm{I}-1$ & 1428 & 155.4 & 13.70 & T-PROBE \\
\hline & $26 \mathrm{I}-1$ & 1428 & 232.8 & 17.93 & T-PROBE \\
\hline \multirow[t]{4}{*}{$731 \mathrm{~A}$} & BW & 2366 & 0 & (2.5) & HYDRO \\
\hline & $71-6$ & 2366 & 66.0 & 5.70 & T-PROBE \\
\hline & $19 \mathrm{I}-1$ & 2366 & 174.4 & 10.52 & T-PROBE \\
\hline & $26 \mathrm{I}-1$ & 2366 & 242.3 & 14.35 & T-PROBE \\
\hline
\end{tabular}

${ }^{\mathrm{a}} \mathrm{BW}=$ bottom water.

${ }^{b} \mathrm{NR}=$ no record; ${ }^{*}=$ temperature drifts up, minimum sediment temperature; ${ }^{\#}=$ temperature drifts up and possible probe disturbance, minimum probable temperature. Values in parentheses indicate more than usual uncertainty - see text for explanation.

${ }^{c}$ HYDRO = regional hydrography (Sastry and D'Sousa, 1971); TPROBE $=$ WSTP thermistor probe; XBT $=$ expendable bathythermograph.

Table 2. Leg 117 heat flow.

\begin{tabular}{lrccc}
\hline Hole & $\begin{array}{c}\text { Depth } \\
\text { interval } \\
\text { (mbsf) }\end{array}$ & $\begin{array}{c}\text { Thermal } \\
\text { gradient } \\
(\mathrm{K} / \mathrm{km})\end{array}$ & $\begin{array}{c}\text { Average thermal } \\
\text { conductivity } \\
(\mathrm{W} / \mathrm{m}-\mathrm{K})\end{array}$ & $\begin{array}{c}\text { Heat flow } \\
\left(\mathrm{mW} / \mathrm{m}^{2}\right)\end{array}$ \\
\hline $723 \mathrm{C}$ & $0-68$ & 50.0 & $\mathrm{a}_{1.25}$ & 63 \\
$726 \mathrm{~A}$ & $0-36$ & $\mathrm{~b}(100.0)$ & $\mathrm{a}_{1.65}$ & $\mathrm{~b}(165)$ \\
$727 \mathrm{~A}$ & $0-96$ & 44.5 & 1.25 & 56 \\
$728 \mathrm{~B}$ & $0-50$ & 44.0 & 1.40 & 62 \\
& $107-233$ & 54.0 & 1.20 & 65 \\
$731 \mathrm{~A}$ & $0-242$ & 47.0 & 1.25 & 59 \\
\hline
\end{tabular}

Note: Values in parentheses indicate more than usual uncertainty - see text for explanation.

${ }^{a}$ No thermal-conductivity measurements made at this hole. Value is estimated from wet-bulk density profile of this site and thermal conductivity vs. wet-bulk density plot for other Oman margin sites (727 and 728).

${ }^{\mathrm{b}}$ Gradient possibly nonlinear, minimum total heat flow.
Shipley, T. H., and Shephard, L. E., 1982. Temperature data from the Mexico drilling area: report on logging and inhole temperature experiments. In Watkins, J. S., Moore, J. C., et al., Init. Repts. DSDP, 66: Washington (U.S. Govt. Printing Office), 771-774.

Uyeda, S., and Horai, K., 1982. Heat flow measurements on Deep Sea Drilling Project Leg 60. In Hussong, D. M., Uyeda, S., et al., Init. Repts. DSDP, 60: Washington (U.S. Govt. Printing Office), 789800.

\section{Ms 117A-120}

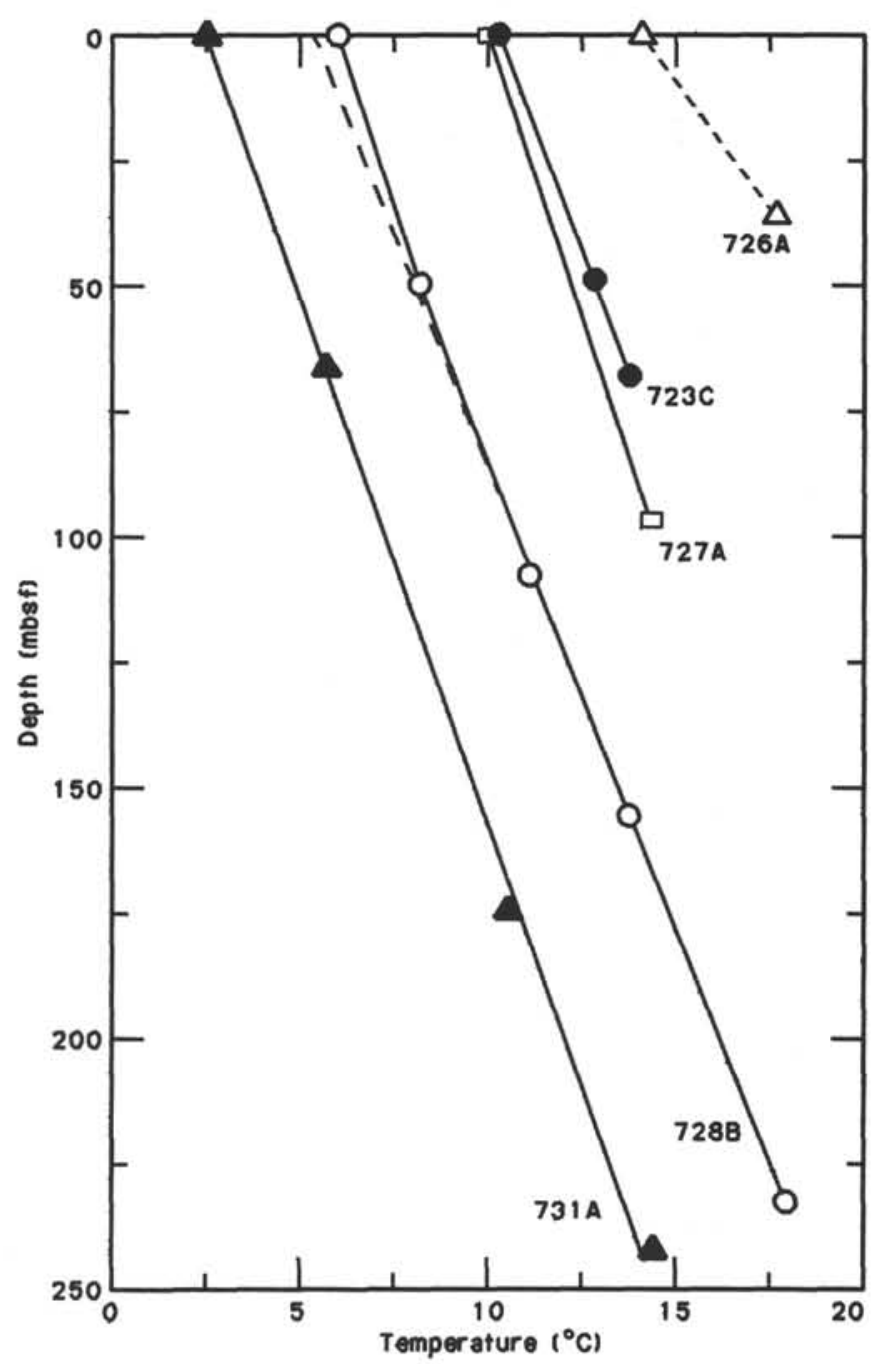

Figure 2. Leg 117 temperature profiles. 